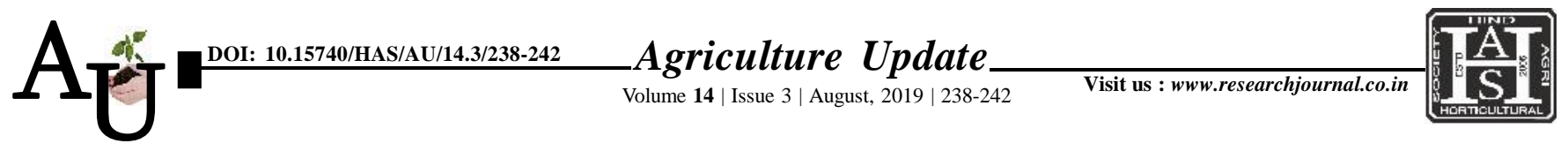

ISSN-0973-1520

\title{
Research Article: Knowledge of the farm women regarding the various agricultural activities
}

\section{J. I. Shaikh and S. B. Shinde}

Article Chronicle: Received :

12.06.2019;

Revised :

13.07.2019;

Accepted :

24.07.2019

KEY Words :

Farm women, Agricultural activities, Knowledge

Author for correspondence :

\section{J.I. Shaikh}

Department of

Extension Education,

Mahatma Phule Krishi

Vidyapeeth, Rahuri,

Ahmednagar (M.S.) India

See end of the article for

authors' affiliations
SUMMARY : The international development community has recognized that the agriculture is an engine of growth and poverty reduction in countries where it is the main occupation of the poor. But the agriculture sector in many developing countries is under performing, in part because women, who represent a crucial resource in agriculture and the rural economy through their roles as farmers, laborers and entrepreneurs, almost everywhere face more severe constraints than men in access to productive resources. The knowledge of farm women regarding various agricultural activities was higher namely bird watching, harvesting, intercultural operations and lower in land preparation activities, marketing, post-harvest operations, seed bed preparation and processing activities. The majority $(71.50 \%)$ of the respondents had medium level knowledge about the various agricultural activities followed by 25.50 per cent of the respondents had low and 3.00 per cent of the respondents had high level of knowledge.

How to cite this article : Shaikh, J.I. and Shinde, S.B. (2019). Knowledge of the farm women regarding the various agricultural activities. Agric. Update, 14(3): 238-242; DOI : 10.15740/HAS/AU/14.3/238-242. Copyright@ 2019: Hind Agri-Horticultural Society. 